\title{
ISLAM JAWA DAN AKULTURASI BUDAYA: Karakteristik, Variasi dan Ketaatan Ekspresif
}

\author{
Ummi Sumbulah \\ Fakultas Syariah UIN Maulana Malik Ibrahim Malang \\ Telp.08123399922, email: ummisumbulah@gmail.com
}

\begin{abstract}
Javanese Islam has a character and a unique religious expressions. This is because the spread of Islam in Java, more dominant takes the form of acculturation, both absorbing and dialogical. The pattern of Islam and Javanese acculturation, as well as can be seen on the expression of the Java community, is also supported by the political power of Islamic kingdom of Java, especially Mataram which had brought Islam to the Javanese cosmology Hinduism and Buddhism. Although there are fluctuations in the relation of Islam to the Javanese culture, especially the era of the 19th century, but the face looks acculturative Javanese Islam dominant in almost every religious expressions Muslim communities in this region, so the aspect of "syncretic" and tolerance of religions into one distinctive cultural character of Javanese Islam.
\end{abstract}

Agama Islam di Jawa memiliki karakter dan ekspresi keberagamaan yang unik. Hal ini karena penyebaran Islam di Jawa, lebih dominan mengambil bentuk akultrasi, baik yang bersifat menyerap maupun dialogis. Pola akulturasi Islam dan budaya Jawa, di samping bisa dilihat pada ekspresi masyarakat Jawa, juga didukung dengan kekuasaan politik kerajaan Islam Jawa, terutama Mataram yang berhasil mempertemukan Islam Jawa dengan kosmologi Hinduisme dan Budhisme. Kendati ada fluktuasi relasi Islam dengan budaya Jawa terutama era abad ke 19-an, namun wajah Islam Jawa yang akulturatif terlihat dominan dalam hampir setiap ekspresi keberagamaan masyarakat muslim di wilayah ini, sehingga "sinkretisme" dan toleransi agama-agama menjadi satu watak budaya yang khas bagi Islam Jawa.

Key words: Javanese Islam, character, acculturation, syncretic 


\section{Pendahuluan}

Istilah Islam Jawa dalam konteks tulisan ini dipahami sebagai sistem keyakinan dan ibadah setempat yang berbeda dengan tradisi Islam pada umumnya. Dengan demikian, kajian ini juga merujuk pada beragam praktik iman, ritual, keyakinan dan religiusitas masyarakat muslim yang berkembang pada waktu dan wilayah tertentu terutama di Jawa. Dalam konteks ini, bisa dilihat bahwa Islam Jawa memberi warna, menyerap bahkan mengislamkan budaya pribumi dan memasyarakatkan kitab suci. Sebagai wujud artikulasinya, bisa dicermati pada beberapa kasus di mana unsur-unsur ibadah pra-Islam diberi makna Islam, dan dalam kasus lain juga dilakukan interpretasi terhadap unsur-unsur tradisi tekstual untuk merumuskan ibadah naratif, ritual dan sosial (Esposito, 2001: 50-51).

\section{Sinkretisme Agama sebagai Karakteristik Islam Jawa}

Islam datang ke bumi Jawa di saat budaya dan tradisi non-Islam terutama Hindu dan Budha telah mengakar kuat dalam masyarakat Jawa. Karya Clifford Geetz yang berjudul The Religion of Java, menjadi rujukan utama hampir seluruh peneliti Barat yang concern mengkaji agama Jawa, seperti Robert W. Hefner (1985 dan 2000), Mark R. Woodward (1998) dan 1989), Niels Mulder (1999), Andrew Beatty (2001), dan Andre Moller (2005), maupun para peneliti Indonesia seperti Abdul Munir Mulhan (2000), Erni Budiwanti (2000), Muhaimin AG (2001), dan Nursyam (2004).

Dalam buku The Religion of Java, Geertz mendeskripsikan secara mendalam fenomena agama Jawa, dengan menggunakan tiga tipologi, yakni abangan, santri dan priyayi (Geertz, 1964: 64). Varian abangan dan santri mengacu kepada afiliasi dan komitmen keagamaan, sementara varian priyayi merupakan kategorisasi sosial. Abangan merupakan sebutan bagi mereka yang tidak secara taat menjalankan komitmennya terhadap aturan keagamaan. Santri merupakan sebutan bagi mereka yang memiliki komitmen keagamaan yang diukur berdasarkan tingkat ketaatannya menjalankan serangkaian aturan agama. Priyayi merupakan sebutan bagi mereka yang secara sosial maupun ekonomi dianggap memiliki derajat dan stratifikasi lebih tinggi dibandingkan dengan kebanyakan masyarakat desa di Jawa.

Dengan menggunakan ketiga tipologi tersebut, Geertz ingin menegaskan bahwa agama Islam di Jawa merupakan kumpulan ekspresi iman, doktrin, ritual dan lan-lain yang dipraktikkan masyarakat sesuai dengan tradisi lokal atau tempat dan waktu seiring dengan perkembangan dan penyebarannya. 
Dalam konteks inilah kehadiran Islam di Indonesia khususnya Jawa, mengambil bentuk akomodasi, integrasi, menyerap dan dialog dengan akar-akar dan budaya non-Islam, terutama animisme dan hinduisme.

Memperkuat tesis di atas, Geertz juga menyatakan bahwa Islam yang hadir di Indonesia bukanlah membangun peradaban tetapi merebut peradaban. $\mathrm{Hal}$ ini dalam pandangan Geertz berbeda dengan kehadiran Islam di Maroko yang mengambil bentuk membangun peradaban. Islam di Maroko lahir 50 tahun setelah wafatnya Rasulullah SAW dan dibawa oleh dinasti Idrisiyah. Karena konteks Jawa yang melatari munculnya Islam di Jawa adalah animisme dan hinduisme, maka logis jika "warna dan citarasa" Islam yang berkembang di Jawa juga bernuansa animisme dan hinduisme. Hal ini bisa disaksikan hingga sekarang dalam berbagai sistem ritual Jawa, seperti slametan dengan berbagai bentuknya, baik slametan dalam rangkaian acara mantenan, khitanan, bersih desa maupun ekspresi keberagamaan lainnya.

Ritual slametan juga menjadi salah satu media kelompok abangan dalam mengekspresikan wajah komitmen dan keagamaannya. Varian abangan juga merupakan representasi keagamaan dengan afiliasinya pada animisme. Hal ini bisa dilihat dari ekspresi kelompok ini dalam berbagai ritual slametan, magis, "perdukunan" dan lain-lain. Varian abangan pada umumnya berpusat di desa, dimana slametan merupakan inti ritual agama Jawa yang paling popular dan bertahan hingga sekarang. Slametan yang berwujud tingkeban, yakni ritual yang dilasanakan bagi perempuan yang mencapai usia hamil tujuh bulan ke atas, kelahiran, kematian, bersih desa, sunatan dan lain-lain, masih terlihat dominan pada kehidupan masyarakat Jawa, baik yang beragama Islam murni maupun Islam Jawa (sinkretis). Bagi kelompok/varian Jawa, terdapat keyakinan bahwa kehidupan, penderitaan, kematian dan keberkahan, merupakan pemberian roh-roh halus yang harus dipuja melalui berbagai ritual tersebut.

Bagi kelompok abangan, slametan diyakini merupakan simbolisme persembahan terhadap para roh halus, roh leluhur dan lain-lain agar masyarakat terhindar dari bencana dan kejahatan. Fenomena slametan yang dianggap sebagai ritual paling inti dalam masyarakat Jawa ini, bisa disimak pada temuan penelitian Beatty ketika melakukan kajian di Bayu, nama sebuah desa di sebelah selatan kota Banyuwangi. Temuan senada juga bisa dilihat pada hasil penelitian Woodward (1998) tentang masyarakat Jawa di Yogyakarta. Memperkuat tesis Geertz, temuan Hefner pada ekspresi keberagamaan masyarakat Pasuruan juga semakin melengkapinya (Hefner, 1985: 91-128).

el Harakah Vol.14 No.1 Tahun 2012 
Dari berbagai temuan beberapa peneliti di atas, dapat disimpulkan bahwa elemen masyarakat Jawa yang memiliki diversitas ternyata bisa disatupadukan melalui ritual slametan tersebut. Hal ini karena dalam slametan, seakan tidak ada jarak antara si kaya dan si miskin, antara penganut Islam normatif dan Islam Jawa (abangan dalam kategorisasi Geertz). Bukti lain bahwa ritual slametan agama Jawa bisa menyatupadukan berbagai varian, bisa dilihat pada temuan Beatty (2001), bahwa pada masyarakat Bayu, terdapat ritual penyembahan kepada Buyut Cili dan Buyut Cungking, atau kultus Nyai Po pada masyarakat Pasuruan sebagaimana ditemukan Hefner yang diikuti oleh seluruh elemen masyarakat (Hefner, 2000: 109-110).

Dalam ritual slametan, semua eleman masyarakat, mulai dari penganut animisme, mistisime, Islam normatif, kejawen dan hinduisme hadir tanpa membawa serta atribut dan simbol-simbol yang membedakan satu dengan yang lain. Menu slametan biasanya terdiri dari nasi kuning dan apem yang dimakan secara bersama-sama segera setelah dipimpin doa oleh seseorang yang "dituakan". Doa biasanya diawali dengan puji-pujian (shalawat) kepada Nabi Muhammad SAW dan para sahabat, namun kemudian sang pemimpin doa juga memanjatkan doa tersebut kepada para leluhur dan danyang desa (Hefner, 2000: 107). Bahkan dalam tradisi ritual yang dilakukan oleh kelompok Islam normatif-pun, juga tidak jarang menggunakan tradisi animisme, pra-Islam. Hal ini bisa dilihat pada ritual khitanan di Bayu, setelah ritual penyunatan selesai, dilakukan pemberian tiga warna pada penis si sunat, yakni warna merah yang berasal dari darah ayam, warna kuning dari kunyit dan warna putih dari air kapur. Hal ini dimaksudkan sebagai upaya menolak bala yang mungkin saja bisa datang sewaktu-waktu. Fenomena ritual lainnya yang menjadi media integrasi dari seluruh elemen masyarakat Jawa adalah penyembahan Buyut Cili dan Buyut Cungking di sebuah keramat. Juru kunci keramat yang memimpin upacara penyembahan adalah orang yang fasih membaca doa-doa secara Islam murni (Islam normatif), namun juga fasih melafalkan mantera-mantera Jawa untuk menghadirkan roh Sang Buyut. Ritual keagamaan ini biasanya juga diawali dengan mantera dan doa tersebut. Ritual-ritual tersebut, tampaknya juga didasari pada konsepsi dasar keyakinan orang Jawa mengenai dunia gaib, bahwa semua perwujudan dalam kehidupan disebabkan oleh mahluk berpikir yang juga memiliki kehendak sendiri (Muchtarom, 2002: 56-57).

Pemandangan-pemandangan paradoksal di atas, menggambarkan betapa Islam di Jawa dibangun dengan tradisi-tradisi pra-Islam, yang membentuk uniformitas dalam diversitas. Mereka yang berasal dari elemen, latar belakang 
dan orientasi ideologis yang berbeda, berintegrasi secara kokoh melalui beragam ritual. Dalam konteks ini pula, tesis Weber bahwa ritus dan mitos merupakan alat integrasi dan harmonisasi kosmis menemukan relevansinya. Ritual slametan yang dalam temuan Geertz lebih kental dilakukan oleh varian abangan, tetapi menurut Beatty dilakukan oleh hampir semua elemen masyarakat, memiliki makna, yakni: pertama, bahwa slametan merupakan jembatan teologis bagi kelompok santri dan abangan. Melalui slametan, baik santri maupun abangan mengikuti satu pakem yang sama bagaimana slametan dilaksanakan, tanpa menanggalkan atribut perbedaan masing-masing. Kedua, slametan merupakan media penyatuan dan integrasi masyarakat. Oleh karena itu beberapa di antara penganut muslim yang taat juga mengadakan berbagai ritual slametan sebagaimana yang dilaksanakan masyarakat pada umumnya, dengan alasan untuk menjaga kebersamaan, menghindari chaos dan bahkan resistensi dari masyarakat. Demikian temuan Beatty dalam penelitiannya di Bayu, sebuah desa di Banyuwangi selatan. Fenomena yang sama juga penulis temukan di sejumlah desa di Malang, yang memiliki basis sejarah kerajaan Jawa (Singosari dan Gajayana), bahwa slametan di kuburan (pemakaman) yang disebut nyadran sering dilaksanakan oleh masyarakat, baik oleh yang abangan maupun yang "santri" sekalipun. Ketiga, slametan merupakan wahana atau forum pertemuan antara si kaya dan si miskin. Demikian Woodward yang menyatakan bahwa slametan memiliki implikasi ekonomis bagi distribusi ekonomi (keberkahan) yang dalam konteks Islam dikenal dengan sebutan shadaqah. Oleh karena itu, Woodward berkesimpulan bahwa ritual slametan memiliki basis teologisnya dalam tradisi Islam. Proses liturgis (tata urutan peribadatan) yang diawali dengan doa yang ditujukan kepada Nabi Muhammad dan para tokoh suci Islam, tampaknya juga semakin memperkuat tesis Woodward tersebut (Woodward, 1998: 55-89).

Kesimpulan Woodward berbeda dengan temuan Geertz, Beatty dan Ricklef bahwa ritual slametan itu murni berakar pada tradisi hinduisme (agama pra Islam). Namun demikian, penulis lebih sepakat bahwa slametan, berakar dari dua tradisi, tradisi pra-Islam dan sekaligus dalam tradisi Islam. Slametan, meskipun ada unsur dan elemen Islam, namun lebih banyak dipengaruhi filsafat agama Jawa, yang dibangun berdasarkan tradisi pra -Islam atau bahkan hinduisme. Hal ini misalnya bisa direferensikan pada temuan Hefner di Pasuruan, Beatty di Bayu Banyuwangi, Woorward di Yogyakarya dan Geertz di "Modjokuto" Pare, Jawa Timur (Bruinessen, 1999: xxxiii). 
Varian priyayi temuan Geertz yang pada umumnya memiliki afiliasi teologis pada hinduisme ini, dikritik oleh ilmuan-ilmuan berikutnya. Hal ini karena pada realitasnya ditemukan banyak juga priyayi yang shaleh, sebagaimana ditemukan Woodward. Oleh karena itu, berdasarkan temuannya, Woodward membuat klalifikasi agama rakyat di Jawa, pada abangan priyayi sebagai Islam Jawa, pengikut kebatinan sebagai kejawen, dan pemegang ortodoksi Islam sebagai Islam normatif, serta mistisisme yang direpresentasikan oleh raja (Woodward, 1998: 301-323).

Varian ketiga dalam temuan Geertz adalah santri. Kelompok ini mengekspresikan keagamaannya melalui seni, etiket, pakaian, bahasa, dan mistik. Kelompok priyayi, seringkali menjadi tempat bergantung para petani (abangan) karena mereka dianggap memiliki keunggulan politis, kharismatis bahkan ekonomis. Para mistikus Jawa ini biasanya menggunakan bahasa khas kromo inggil dan bahkan bahasa Belanda untuk menunjukkan eksklusivitasnya sebagai kelompok yang biasanya menguasai basis pemerintahan/kota. Bahasa Jawa ngoko hanya digunakan oleh kelompok ini untuk berkomunikasi dengan para buruh atau pembantu mereka.

Varian santri merupakan kelompok keagamaan yang menjunjung tinggi doktrin keagamaan. Mereka memiliki tingkat kepatuhan yang tinggi terhadap doktrin agama. Oleh karena itu, upacara-upacara keagamaan yang dilakukan kelompok yang menguasai basis di pasar atau perdagangan ini juga mengacu kepada ritual yang dituntunkan atau terkait dengan sejumlah ortodoksi Islam. Demikian juga tempat ritual, dilakukan di masjid, mushalla atau institusi-institusi keagamaan yang lain. Lembaga pendidikan seperti madrasah dan pesantren merupakan ikonografi khusus kelompok ini, yang cenderung membedakan secara hitam-putih dengan varian abangan dan priyayi. Kendati varian santri ini tampak ada pemilahan dan penjelasan secara rigid dan dibedakan dari dua varian yang lain, abangan dan santri, namun sesungguhnya dalam kehidupan praksis kategori-kategori tersebut mengalami kekaburan dan ambiguitas. Demikian kesimpulan Beatty, sehingga ia menghindari melakukan kategorisasi masyarakat berdasarkan tingkat dan komitmen keagamaannya sebagaimana dilakukan Geertz. Berdasarkan data penelitian di atas, dapat diambil pemahaman bahwa fenomena agama di Jawa bisa disebut sebagai agama sinkretis meskipun Woodward lebih suka menyebutnya sebagai Islam Jawa, sama seperti Islam India, Islam Melayu, dan Islam Timur Tengah. Hal itu karena masing-masing memiliki ciri, karakteristik dan keunikan tersendiri sehingga membuat agama tersebut terkesan "lebih hidup" karena sarat dengan makna dan dimensi. 


\section{Islam Jawa dan Akulturasi Budaya}

Menurut Taufik Abdullah bahwa akulturasi budaya Jawa dan Islam di Jawa mengambil bentuk dialogis (Abdullah, 1989: 58-99). Berbeda dengan akulturasi Islam dengan budaya Melayu yang mengambil bentuk integratif. Islam dihadapkan pada resistensi tradisi dan budaya lokal, sehingga ketegangan dan konflik Islam versus Kejawen menjadi ciri utama perkembangan Islam di Jawa, terutama pada abad ke-19 atau masa kolonial. Akulturasi budaya Jawa dan Islam dengan pola dialogis, dipahami bahwa Islam dan budaya Jawa berkomunikasi dalam bentuk struktur sosial-agama. Adapun relasi Islam dan budaya Melayu yang mengambil pola integrasi, dipahami bahwa Islam berkembang dan menjadi salah satu penyangga terpenting dalam struktur politik Melayu.

Perkembangan Islam di Jawa mencapai prestasi yang dinilai cukup signifikan sehingga menghadirkan fenomena Islam Jawa yang unik hingga sekarang ini, adalah pada saat pergeseran kerajaan Islam dari daerah pesisir (Demak) ke daerah pedalaman agraris (Mataram) di bawah kekuasaan Sultan Agung pada abad ke-17 (Abdullah, 1989: 58-99). Pada masa Sultan Agung ini, mistisisme Jawa mengalami perkembangan yang artikulatif. Raja atau sultan dianggap sebagai guru sufi dan kosmologi Hindu-Budha bertemu dalam wadah sufisme tersebut.

Dalam konteks Jawa, kota atau keraton menjadi representasi jalan mistik sufi dan kosmos Islam, sehingga sultan dianggap sebagai wali, sosok manusia yang dianugerahi bertumpuk kemuliaan. Keyakinan masyarakat Jawa bahwa Sultan merupakan wali, diperkuat dengan ikonografi bahwa keraton dikelilingi oleh 33 kampung yang menggambarkan jumlah surga di gunung Meru, Allah bersemayam di hati, sehingga setiap manusia (raja) menjadi jembatan ketuhanan makrokosmos. Dalam konteks mistisisme Jawa, semua entitas terkategorisasi ke dalam dua macam, yakni wadah dan isi. Wadah adalah alam, tubuh, rakyat, dan Islam normatif, sedangkan isi adalah Tuhan, raja, mistik, dan rohani.

Rakyat sebagai wadah tidak boleh meninggalkan syariat, sementara raja sebagai isi dan penggagas mistisisme, dianggap boleh saja meninggalkan syariat. Dalam konteks ini, Woodward menyatakan bahwa Islam Jawa memang diwarnai ketegangan antara penafsiran legal dan penafsiran mistis, namun keduanya memiliki sumber yang sama, Islam. Oleh karena itulah, ia kemudian memperkenalkan varian Islam berupa "Islam normatif" dan "Islam Jawa", dengan menyatakan bahwa Islam membentuk karakter 
interaksi sosial dan kehidupan sehari-hari di semua lapisan masyarakat Jawa (Woodward, 1998: 3).

Senada dengan tesis di atas, Geertz juga menemukan data menarik. Geertz menyatakan bahwa Islamisasi Jawa yang antara lain dilakukan oleh Sunan Kalijaga adalah membawa dunia Hindu pewayangan ke dunia Islam kitab suci. Dengan demikian, Islamisasi di Jawa dilakukan dengan mengakomodasi tradisi dan dinamisme lokal. Hal ini tentu berbeda dengan temuan Geertz di Maroko, di mana Islam dikembangkan oleh Lyusi dengan wajah menentang tradisi dan dinamisme lokal, dengan pendekatan purifikatif.

Pola Islamisasi Jawa yang akomodatif dan menyerap tradisi dan dinamisme lokal tersebut, tercermin dalam berbagai karya sastra di era ini. Karya sastra atau serat dimaksud, menggambarkan pola akulturasi Islam dan budaya Jawa, seperti terillustrasikan antara lain dalam Babad Tanah Jawa dan Serat Centhini. Sufisme dalam serat tersebut digambarkan menjadi budaya Jawa dengan terma-terma sufistis yang khas Jawa bahkan berbahasa Jawa.

Dengan pola Islamisasi Jawa (ada juga yang menyebutnya dengan istilah jawanisasi Islam) seperti itu, logis jika pada tahap berikutnya orang Jawa memiliki toleransi yang tingi terhadap budaya atau penganut agama lain. Temuan Anderson dalam karyanya "Mitologi dan Toleransi Orang Jawa, menyatakan orang Jawa memiliki toleransi tinggi terhadap penganut agama-agama lain, sebagaimana tergambarkan dalam petikan berikut (Anderson, 2000: 4):

"Sudah tentu saya orang Islam, tetapi bukan orang muslim yang fanatik seperti orang Aceh. Kami orang-orang Jawa bisa bergaul dengan orang-orang Kristen dan Budha. Kami melihat kebenaran dalam semua agama dan tidak hanya (eksklusif) dalam kepercayaan kami."

Toleransi dan penghargaan terhadap agama dan residuum budaya, bagi orang Jawa merupakan sebuah kebanggaan. Sikap ini, kata Anderson, sangat terkait dengan mitologi Jawa yang terillustrasikan melalui dunia pewayangan yang terinternalisasikan dalam mindset masyarakat Jawa. Melalui wayang, terdapat berbagai sosok yang merepresentasikan keunikan pribadi masyarakat Jawa. Hal ini misalnya dapat dilihat pada sosok Yudhistira, yang merupakan lambang raja yang bijak dengan jimat suci Kalimasadha; Arjuna sebagai lambang ksatria yang lembut hati dan berkemauan keras; Bima sebagai ksatria pemberani yang tanpa ampun terhadap musuh-musuhnya namun memiliki komitmen pada kejujuran dan kesetiaan; Baladewa sebagai pendidik cucu Arjuna, Parikesit, nenek moyang raja-raja Jawa; Sumbadra sebagai gambaran aristokrat Jawa; 
Kresna sebagai ikon diplomat ulung dan lain-lain. Keseluruhan sosok di atas merupakan gambaran ideal manusia. Namun popularitas masing-masing tokoh dalam dunia pewayangan tersebut akan berbeda-beda, sesuai dengan pengidolaan di masing-masing daerah. Misalnya di Madura, tokoh Baladewa sangat popular, masyarakat Pedesaan di Jawa lebih mengidolakan Semar, dan Soekarno yang mengidolakan Gatotkaca.

Wayang, di samping menjadi pusat idola karakter Jawa, juga menjadi gambaran pertentangan kosmis antara kebajikan dan kesalahan, kebaikan dan kejahatan dan seterusnya. Namun pertentangan dimaksud tidak untuk saling dibedakan karena sarat ambiguitas dan toleransi, yang karenanya justru dapat saling melengkapi. Hal ini misalnya dapat dilihat pada sosok Saliya, seorang ksatria yang mempersunting Setyawati, anak seorang raseksa. Dalam dunia pewayangan, ada penilaian bahwa tidak layak seorang ksatria, yakni Saliya memiliki raseksa dalam keluarganya. Oleh karena itu, raseksa Bagaspati meminta Saliya agar membunuh dirinya, demi kebahagiaan puterinya. Permintaan ayah mertua tersebut dikabulkan Saliya dan berbahagialah ia bersama Setyawati. Gambaran lain tentang hal ini juga bisa dilihat pada sosok Kurawa, yang dinilai tidak baik bukan karena mereka jahat, namun karena mereka adalah satria yang jahat, karena seharusnya satria itu tidak jahat (Anderson, 2000: 14-43).

Gambaran-gambaran mitologi dunia pewayangan itulah antara lain konstruk pemikiran dan budaya yang membuat orang Jawa tampil menjadi sosok yang relatif toleran dan lapang dada. Di era abad ke-17 inilah pola dialogis lebih bernuansa harmonis daripada konfrontatif. Namun sejak abad ke-19, seiring dengan kolonialisme barat atas Indonesia (termasuk Jawa) yang lebih berpihak pada kelompok priyayi, kemudian konflik antara Islam normatif (santri) dengan priyayi tidak terelakkan. Sebagai konsekuensinya, karya satra atau serat yang lahir di era ini, seperti Serat Darmagandhul, Serat Gatholoco dan Serat Cebolek juga bernuansa mendiskreditkan kaum santri. Serat-serat tersebut mewakili ideologi kaum priyayi yang kebanyakan memiliki afiliasi teologis pada animisme dan hinduisme. Hal ini misalnya dapat dilihat pada gambaran-gambaran ideologi dalam serat tersebut tentang kaum santri. Kata Mekkah misalnya, diartikan sebagai mekakah yang dalam bahasa Jawa berarti membuka paha/dua kaki seperti berposisi senggama dan lain-lain. Hal ini tentunya sangat menyinggung kaum santri, karena perilaku atau idiom-idiom kesantrian digambarkan secara negatif dan tidak etis bahkan Islam dianggap sebagai agama asing bagi orang Jawa. 


\section{Ketaatan Ekspresif Islam Jawa}

Ekspresi dan pengungkapan realitas dan tekstur sosial serta tujuan moral dari beragam variasi agama praksis di Jawa, selain dilakukan oleh Clifford Geertz, Robert Hefner, dan Ricklefs, juga dilakukan oleh Andrew Beatty (2001) di desa Bayu, Banyuwangi selatan. Banyuwangi yang merupakan kota paling ujung di Jawa Timur, adalah sosok kota yang penduduknya heterogen, yang terbentuk akibat perpecahan dan marginalisasi politik, sehingga terjadi migrasi. Para migran tersebut adalah Madura, nelayan Mandar dan Bugis, pedagang Cina, Arab, dan etnis Jawa di barat yang oleh penduduk asli Banyuwangi disebut wong kulon(an) atau orang dari barat atau wong Mentaram (orang Mataram), yang pada gilirannya banyak berkolaborasi dengan penduduk asli ketika mengembangkan tradisi keagaman.

Bayu adalah sebuah desa yang memiliki kekayaan budaya dan tradisi keagamaan yang justru melahirkan keharmonisan. Semua elemen masyarakat dari kelas dan ragam manapun berbaur dan melakukan kompromi-kompromi teologis tanpa menimbulkan clash. Ada perasaan dan tanggung jawab bersama menciptakan suasana kehidupan desa yang penuh dengan kedamaian. Oleh karena itu, berbagai ritus terutama slametan, pemujaan roh halus, pertunjukan barong yang bernuansa magis, mitos tempat keramat dan person misalnya, menggambarkan suasana kekaburan hubungan antara elemen-elemen masyarakat di wilayah tersebut.

Dalam konteks agama Jawa di Bayu, eleman masyarakat yang beragam mendatangi slametan tidak dengan menunjukkan ciri khusus masing-masing. Oleh karena itu, terdapat kesamaaan dan kebersamaan dalam keragaman. Kesamaan mantera dan doa yang dipanjatkan selama ritual slametan berlangsung, yang diikuti peserta dari berbagai kalangan (mulai dari penganut mistik, pantheism, agama normatif dan tradisionalis) menunjukkan betapa terjadi percampuran dan akomodasi mendalam dari setiap pihak untuk mengapresiasi tradisi dan budaya yang berkembang secara turun temurun, tanpa dihantui oleh perasaan dan kesalahan karena sinkretisme yang tidak disadari terutama oleh kalangan yang secara nominal memiliki kesalehan agama, namun juga rajin melakukan ritual yang berbau magis.

Dalam setting pedesaan Jawa pedalaman, bukan Jawa pesisir yang didominasi oleh ciri dan karakter agrarisnya, terdapat berbagai ungkapan dan manifestasi kepercayaan terhadap para penguasa melalui ritual slametan, pemujaan roh halus, pertunjukan bernuansa magis, berbagai cara kompromi dengan Islam dan negara modern, Islam praksis yang demikian berbaur kental 
dengan tradisi lokal, hinduisme, dan bahkan sebuah pesta yang bernuansa erotis dan berbau seksualitas seperti digambarkan gandrung.

Kemajemukan dan variasi agama tidak saja terjadi pada masyarakat maju seperti di Barat, tetapi realitas agama praksis pada masyarakat Jawa telah mengatakan hal yang sama, yang dalam proses dan survivalitasnya terdapat beragam komponen yang saling mempengaruhi, mulai dari ketaatan islami, mistisisme, hinduisme dan tradisi lama berikut kompromi-kompromi yang saling diberikan oleh satu elemen kepada elemen yang lain, dalam rangka menciptakan harmonisasi dan integrasi sosial yang kokoh. Fenomena keagamaan dan kebudayaan yang kaya itulah yang diharapkan Beatty untuk dapat disajikan melalui sebuah pendekatan yang dinamik dan absah mengenai bagaimana agama "bekerja" dalam suatu masyarakat yang penuh dengan kompleksitas (Beatty, 2001: 1).

Penelitian agama yang demikian banyak memberikan makna terhadap kompleksitas dan nuansa agama Jawa yang penuh dengan campur aduk dengan kebudayaan lokal, simbolisme kultus, literalisme Islam, mistik dan bahkan hinduisme ini menggunakan paradigma konstruksionisme, yang menekankan pada karakteristik fenomena agama di wilayah tertentu dan karenanya tidak bisa digeneralisir, kendati dalam masyarakat yang berbeda juga ditemukan kemiripan-kemiripan fenomena (Maliki, 2003: 234).

Agama sebagai sistem realitas hidup yang praksis, memiliki daya fleksibilitas, apresiasi dan akomodasi terhadap tradisi dan budaya yang berkembang secara turun temurun di desa Bayu dan sekitarnya tanpa ada yang berani menanyakan validitas dan otentisitasnya. Keyakinan tersebut, diterima dan dipraktikkan sebagai sebuah keniscayaan secara taken for granted, unquitionable serta tidak ada yang berani menentangnya. Berbagai bentuk ritual slametan (panen, bersih desa, pemujaan roh halus, pemakaman dan sunatan) selalu tidak dianggap sah jika menyalahi/berbeda dari apa yang telah diwariskan nenek moyangnya.

Beragam mitos baik menyangkut tempat maupun person, dan munculnya agen pembawa berkah bagi kehidupan masyarakat desa, semakin melengkapi kekayaan ritus masyarakat desa Bayu. Melalui agen inilah, mayarakat yang berniat melakukan slametan untuk meminta kemakmuran dan kesejahteraan hidup sehingga permintaannya tercapai (kabul kajate). Pemujaan roh atau pemujaan leluhur baik sebagai person maupun institusi ini, menurut Dhavamony merupakan salah satu dari bentuk-bentuk primitif agama yang sesungguhnya juga berlaku secara universal, di samping animisme, animatisme, totemisme, 
dan urmonoteisme (Dhavamony, 1995: 65-82).

Fenomena ini, tampaknya juga bisa dilihat misalnya dalam tradisi sufisme Islam, yang menjadikan guru sufi sebagai agen berkah yang bisa diberikan kepada para pengikut/muridnya. Dalam tradisi pesantren, kyai juga bisa dipandang sebagai agen bagi masyarakat/umat yang ingin ngalap berkah. Demikian juga yang bisa dijumpai dalam tradisi agama Kristen misalnya, yang menjadikan pendeta/pastur sebagai agen penebusan dosa lewat ritual penebusan atau pengakuan dosa dan serangkaian ritual pertobatan.

Slametan dengan berbagai atribut, bentuk, dimensi dan maknanya, selalu diupayakan bagi kesinambungan dan harmonisasi kosmik. Slametan merupakan fenomena umum yang menginternalisasi dalam sistem kehidupan masyarakat Jawa, betapapun dapat dinilai merupakan upaya harmonisasi sosial terutama dari Islam dan berbagai tradisi lokal yang seringkali dikemas dalam multivokalitas simbol-simbol ritual yang tidak pernah menghasikan kesepakatan, sarat ambiguitas namun juga penuh keteraturan.

Keterlibatan muslim standard dan yang taat dalam praktik mitologi tempat keramat, karena mereka beranggapan bahwa tempat keramat, pertunjukan magis lewat barong dan berbagai praktik ritualitas tersebut tidaklah terkait dan bahkan berada di luar wilayah dogma dan ajaran agama. Medan budaya seperti itu, hanya dipandang semata-mata sebagai adat, kendati mereka juga menyadari bahwa kunjungan dan keterlibatan mereka terhadap ritualitas itu akan semakin memberikan legitimasi kebenaran dan ketinggian bagi kekeramatan tempat tersebut. Menanggapi fenomena ini, tampaknya menarik disimak pernyataan seorang modin, bahwa ibarat berganti-ganti topi, jika ke masjid memakai kopiah dan jika ke tradisi slametan memakai blangkon. Kopiah merupakan ikon yang menyimbolkan ketaatan terhadap doktrin agama, sedangkan blangkon merupakan ikon yang menyimbolkan ketaatan untuk melestarikan tradisi, yang dalam hal ini juga sempat mengundang polemik apakah blangkon itu adalah kebiasaan Muslim atau Budha (Beatty, 2001: 82). Hal ini menunjukkan bahwa ada semacam keterpisahan antara satu ruang dan medan kehidupan dengan ruang dan medan kehidupan lainnya, yang sesungguhya saling terkait.

Dengan demikian keberadaan mitos untuk menjaga keharmonisan kosmik dalam konteks ini semakin menunjukkan peran pentingnya. Slametan yang dilakukan secara bersama-sama oleh kalangan santri dan kalangan mistik, merupakan upaya harmonisasi dan integrasi sosial, yang dilakukan di atas atribut perbedaan yang tidak menimbulkan pembedaan. Justru dalam 
konteks ini, slametan merupakan pengikat perbedaan dalam satu tujuan yang lebih mulia untuk konteks masyarakat yang memiliki sistem berpikir yang dihegemoni oleh mitos serta berbagai kekuatan supranatural (Siswomiharjo, 2003: 27). Fenomena tersebut juga membuktikan kebenaran tengara Weber sebagaimana dinukil Brian Morris bahwa semua agama memasukkan elemen magis dalam ritus-ritus, sakramen, mite dan doktrinnya (Weber, 2002: 29).

Munculnya ritus-ritus keagamaan pada masyarakat, sesungguhnya terkait dengan tiga hal yaitu pertama, persoalan makna dimana penderitaan, ketakutan, kejahatan dan kematian tidak lepas dari manusia yang karenanya manusia berupaya sekuat tenaga untuk menyelamatkan dirinya; kedua, persoalan kharisma, yakni sebuah konsep relasional yang muncul pada kualitas individu tertentu dan menempatkannya di atas harapan-harapan normal dan memiliki otoritas tertentu untuk memberikan kekuatan atau berkah tertentu bagi orang-orang yang melakukan pemujaan terhadapnya. Hal ini karena, menurut Bellah, bahwa agama berasal dari kekuasaan yang melebihi seluruh kekuatan yang ada di dunia (Bellah, 2003: 10).

Variasi lain yang dapat dilihat dari fenomena keagamaan pada masyarakat Bayu adalah bahwa hampir semuanya mengaku muslim, namun terdapat varianvarian yang paradoksal, inkonsistensial dan ekstrem, yakni pertama, kelompok yang mengaku muslim namun tidak pernah melaksanakan ritualitas doktrin Islam. Kelompok ini berkeyakinan bahwa orang akan dinilai baik karena tidak pernah berbuat jahat kepada tetangga. Kedua, kelompok Islam yang secara statistikal-nominal rajin melaksanakan ritualitas Islam seperti shalat dan zakat, namun dibenci banyak orang karena suka mencela orang lain yang tidak mau mengerjakan shalat seperti dirinya. Ketiga, kelompok minimalis, yang beranggapan bahwa melaksanakan ajaran Islam boleh dilakukan sebisanya, jika tidak mampu melaksanakan shalat lima kali sehari, mereka mencukupkan hanya dengan shalat jum'at dan sebagainya.

Kelompok kejawen atau yang populer disebut sebagai sekte/asosiasi/ paguyuban mistik, merupakan varian lain yang memiliki ekspresi keagamaan yang tidak kalah menarik. Kelompok ini memiliki keyakinan yang dikonstruk melalui perkenalan dan pengalaman sebelum akhirnya diserap menjadi kebenaran yang harus diyakini, bukan melalui dogma agama yang bersumber pada literatur tekstual, sebuah sistem keyakinan yang menghegemoni Islam ortodoks. Bagi kelompok kejawen ini, pemahaman yang sejati adalah membuktikan (mbukteaken) pengetahuan seseorang, mencocokkan dengan realitas. Dengan demikian, kelompok ini beraliran pragmatis dan semi- empiris, sebuah bentuk 
keyakinan yang paradoks dengan keyakinan santri bahwa kebenaran adalah sesuatu yang termuat dalam teks suci, di luar campur tangan manusia.

Konstruk keyakinan kejawen ini didasarkan pada konsep panteism yang merupakan bentuk khusus dari monisme. Paham ini berpandangan bahwa seseorang berasal dari Tuhan dan segala sesuatu terserap ke dalam Tuhan. Dalam diri manusia ada Tuhan, dan semua aktivitas serta perputaran hidup selalu berpusat pada diri sendiri (antroposentrism). Hal ini misalnya dapat dilihat pada ritual thawaf pada haji yang mengelilingi Ka'bah, yang hal ini sesungguhnya menggambarkan sentralitas manusia itu sendiri. Demikian juga proses pencarian Tuhan yang dilakukan Ismail, yang ketika telah mencapai titik kelelahan ia menemukan ide Tuhan pada batu hitam yang belakangan menjadi bangunan ka'bah dan sebagainya (Beatty, 2001: 225).

Hubungan manusia dengan Tuhan yang digambarkan sebagai relasi mikrokosmos-makrokosmos misalnya dapat dilihat dan dipahami dari prototype pria-wanita, Adam dan Hawa. Adam berarti kekosongan, hampa dan Hawa berarti hawa, iklim, elemen, hasrat dan nafsu seksual. Penyatuan seksual Adam dan Hawa karenanya analog dengan pertemuan elemen-elemen di dalam kehampaan purba, awal dari wujud manusia (Beatty, 2001: 235). Konsepsi kelompok ini tentang hubungannya dengan Tuhan, dapat dicapai melalui empat tahap, yakni sare'at, tarekat, hakekat dan ma'ripat sebagai bentuk hubungan tertinggi dalam manunggaling kawula gusti, konsepsi mistisisme yang di Jawa populer diajarkan oleh Syekh Siti Jenar.

Salah satu sekte atau asosiasi mistik yang paling menarik di Bayu adalah sekte Sangkan Paran yang sesungguhnya merupakan sekte mistik tertua di Jawa. Sekte yang didirikan oleh Raden Mas Joyokusuma dan memiliki keterkaitan genealogis dengan keraton Solo ini, berbasis di pedesaan dan telah memiliki jaringan di berbagai kota, mulai dari Ponorogo, Surabaya, Malang dan Solo sendiri. Doktrin sekte ini lebih bernuansa pada pengetahuan kemanusiaan, serangkaian resep moral yang bermakna koreksi diri dan hubungan harmonis dengan orang lain, yang biasanya berbentuk puji-pujian yang lazim ditransformasikan dengan tradisi lisan.

Fenomena menarik yang lain juga terlihat dalam tradisi Hindu Jawa yang kegiatan ritualnya dipusatkan di Glenmore, namun mereka berasal dari beragam penjuru Banyuwangi dan bahkan dari Bali. Hal ini juga tampak pada festival Saraswati, yang kendati berbasis Hindu Jawa namun rangkaian ritualitas berikut simbol-simbolnya lebih bernuansa Hindu Bali. Agama yang survive di desa Krajan ini, sesungguhnya merupakan percampuran dari penduduk asli 
(Osing) serta migran dari Ngawi, Madiun, Nganjuk, Mojokerto dan Blitar, lima kota di Jawa Timur yang juga berbasis Jawa pedalaman (Beatty, 2001: 299). Mereka pada mulanya merupakan penganut muslim nominal eksponen pendukung komunis dan Partai Nasionalis Indonesia. Pasca kerusuhan di tahun 1965-an, di antara mereka banyak yang berkonversi ke Hindu karena merasa banyak memiliki kecocokan spiritual pada agama ini, di samping karena alasan politis. Oleh karena itu, pendeta yang juga didatangkan dari Bali ini juga mengajarkan berbagai indoktrinasi hindusme Bali. Sebagai akibatnya, wajah hinduisme lebih "bercitarasa" Bali daripada Jawa. Namun demikian, keragaman latar belakang, praktik dan karakteristik keagamaan tersebut menghasilkan paduan harmonis dalam keteraturan dan keselarasan.

Fenomena kegamaan dan kehidupan di Bayu, menunjukkan fenomena hubungan yang terangkum dari berbagai diversitas namun menghasilkan uniformitas yang harmonis. Harmonisasi kehidupan yang sesungguhnya tidak nir konflik ini, dapat dilihat misalnya pada dialektika antara santri tua (konservatif) vis a vis santri muda, kelompok Islam konservatif yang menguasai bacaan-bacaan dan teks-tekas Arab versus kelompok reformis yang tidak pandai mambaca teks Arab namun memiliki pandangan lebih luas tentang kehidupan (Beatty, 2001: 194).

Kekayaan dan kompleksitas spiritual masyarakat Bayu ini, semakin memberikan kesimpulan bahwa kultural dan ritualitas keagamaan Islam konservatif khususnya, tidak berdiri sendiri tetapi bertautan langsung dengan setting spiritualitas masyarakat di era sebelumnya. Dalam konteks ini, agaknya tepat ungkapan bahwa sesungguhnya yang dilakukan oleh para Wali Songo di Jawa bukanlah islamisasi Jawa tetapi jawanisasi Islam. Agaknya kesimpulan ini, juga memiliki relevansi ketika dicocokkan pada realitas keagamaan praksis yang dapat disimak pada masyarakat Bayu sebagaimana dipaparkan sebelumnya. Bagaimana doktrin Islam dicampuradukkan dengan ritual yang sama sekali berbeda dan tidak ada sumber doktrinalnya dalam Islam. Banyak kaum mistikus yang biasanya memimpin ritual slametan juga fasih melafalkan doa-doa yang biasa dibaca oleh kelompok santri. Sebaliknya terdapat kelompok santri yang di samping rajin ke masjid, juga rajin mengunjungi tempat keramat serta fasih melafalkan doa-doa atau mantera-mantera yang khas mistis dan digunakan sebagai mediasi hubungan dengan leluhur yang dipercayai memiliki kekuatan magis dan spiritual. Menyikapi realitas keberagamaan yang sangat variatif tersebut, tampaknya lima dari enam cara beragama yang ditawarkan Dale Cannon yang penuh dengan nuansa simbolik, menemukan signifikansinya. 
Enam cara beragama tersebut adalah ritus suci, perbuatan benar, ketaatan, mediasi samanik, pencarian mistik serta penelitian akal, yang kesemuanya merupakan apresiasi dan manifestasi relasi hamba dengan kekuatan di luar manusia yang disebut sebagai Realitas Mutlak (Cannon, 2002: 77).

\section{Simpulan}

Dibandingkan dengan daerah-daerah lain di Indonesia, toleransi orang Jawa terhadap agama-agama lain, secara umum masih tinggi. Bahkan dalam penilaian para antropolog, toleransi yang diekpresikan Islam Jawa bukanlah toleransi murni, namun telah mengalami semacam "sinkretisme" ekspresif dengan tradisi pra-Islam, khususnya anismisme dan hinduisme. Dengan demikian, hampir tidak ada batas antara toleransi dan sinkretisme Islam Jawa dengan agama-agama lain. Hal ini karena mereka memiliki kebajikan dan kearifan lokal (local wisdom) yang diserap dari berbagai akar budaya, ajaran falsafah dan agama serta tradisi yang sudah mengakar kuat di bumi Jawa, bahkan jauh sebelum kehadiran Islam di nusantara ini.

Agama praktis yang tampil demikian elegan dan artikulatif pada Islam Jawa, menunjukkan demikian variatif dan kompleksnya respon, pemahaman dan penghayatan masyarakat terhadap realitas spiritual. Variasi kelompok mistik dan berbagai ordo mistisisme seperti kejawen maupun Sangkan Paran, Islam tradisionalis-skripturalis/reformis berikut tingkat ketaatan secara nominalstatistikal maksimalis, minimalis, maupun kesalehan sosial ansich, dengan segala kelebihan dan kelemahan masing-masing, telah membuka mata betapa watak spiritual-kultural masyarakat Jawa demikian tinggi.

\section{Daftar Pustaka}

Abdullah, Taufik. 1989. "Islam dan Pembentukan Tradsisi di Asia Tenggara" dalam Taufik Abdullah dan Sharon Siddique. Tradisi dan Kebangkitan Islam di Asia Tenggara. Jakarta: LP3ES.

AG, Muhaimin. 2001. Islam dalam Bingkai Budaya Lokal Potret dari Cirebon. Jakarta: Logos.

Anderson, Benedict C. 2000. Mitologi dan Toleransi Orang Jawa.Yogyakarta: Qalam.

Beatty, Andrew. 2001. Variasi Agama di Jawa: Sebuah Pendekatan Antropologi. Jakarta: Murai Kencana. 
Bellah, Robert N, dan Phillip E. Hammond. 2003. Varieties of Civil Religion. Yogyakarta: IRCiSoD.

Budiwanti, Erni. 2000. Islam Sasak, Islam Wetu Lima Versus Wetu Telu. Yogyakarta: LKiS.

Bruinessen, Martin van, dalam Robert W. Hefner. 1999. Geger Tengger: Perubahan Sosial dan Perkelahian Politik. Yogyakatya: LKiS.

Cannon, Dale. 2002. Six Ways of Being Religious. Alih bahasa oleh Jam'annuri dan Sahiron. Diperta Depag RI-CIDA McGill-Project.

Dhavamony, Mariasusai. 1995. Fenomenologi Agama. Yogyakarta: Kanisius.

Esposito, John L (ed.). 2001. Ensiklopedi Oxford Dunia Islam Modern Jilid I. Mizan: Bandung.

Geertz, Clifford. 1964. The Religion of Java. London: Free Press of Glecoe.

Hefner, Robert W. 2000. Islam Pasar Keadilan: Artikulasi Lokal, Kapitalisme dan Demokrasi.Yogyakarta: LKiS.

Hefner, Robert W. 1985. Hindu Javanese: Tengger Tradition and Islam. Princetone: Princetone University Press.

Maliki, Zainuddin. 2003. Narasi Agung Tiga Teori Sosial Hegemonik. Surabaya: LPAM.

Morris, Brian. 2003. Antropologi Agama: Kritik Teori-teori Agama Kontemporer. AK Group. Yogyakarta.

Moller, Andre. 2005. Ramadan di Jawa Pandangan dari Luar. Jakarta: Nalar.

Muchtarom, Zaini. 2002. Islam di Jawa dalam Perspektif Santri dan Abangan. Jakarta: Salemba Diniyah.

Mulder, Niels. 1999. Agama, Hidup Sehari-hari dan Perubahan Budaya. Jakarta: Gramedia Pustaka Utama.

Mulkhan, Abdul Munir. 2000. Islam Murni pada Masyarakat Petani.Yogayakarta: Bentang Budaya.

Nursyam. 2004. Islam Pesisir. Yogyakarta: LkiS.

el Harakah Vol.14 No.1 Tahun 2012 
Siswomiharjo, Koento Wibisono. 2003. Diktat Kuliah Filsafat Ilmu. IAIN Surabaya: Pascasarjana.

Weber, Marx. 2002. Sosiologi Agama. IRCiSoD. Yogyakarta.

Woodward, Mark R. 1988. "The Slametan: Textual Knowledge and Ritual Performance in Central Javanese Islam" dalam Journal of History of Religion, 28. 55-89.

Woodward, Mark R. 1989. Islam in Java: Normative Piety and Mysticism in the Sultanate of Yogyakarta. Tucson: The University of Arizona Press. 